\title{
The Paleoproterozoic Singo Granite in south-central Uganda revealed as a Nested Igneous Ring Complex using Geophysical Data
}

Mohamed G. Abdelsalam*, Andrew B. Katumwehe, Estella A. Atekwana, Alan K. Le Pera,

\author{
Mercy Achang \\ Boone Pickens School of Geology \\ Oklahoma State University \\ 105 Noble Research Center \\ Stillwater, OK, 74078. USA \\ *Corresponding author e-mail: mohamed.abdel_salam@okstate.edu
}

Submitted to Journal of African Earth Sciences July 2015

Revised September 2015 


\section{Abstract}

We used high-resolution airborne magnetic and radiometric data and satellite gravity data to investigate the form of occurrence of the Paleoproterozoic Singo granite in west-central Uganda. This granitic body covers an area of $\sim 700 \mathrm{~km}^{2}$, intrudes Paleoproterozoic crystalline rocks and overlain by Paleoproterozoic-Mesoproterozoic sedimentary rocks, both of which belong to the Rwenzori terrane, and it is host to hydrothermally-formed economic minerals such as gold and tungsten. Our analysis provided unprecedented geometrical details of the granitic body and revealed the following: (1) the margins of the Singo granite are characterized by a higher magnetic signature compared to the interior of the granitic body as well as the surroundings. These anomalies are apparent in both the total magnetic field and horizontal derivative images and define eight overlapping ring features. (2) the depth continuation of these magnetic anomalies define outward but steeply-dipping features as indicated by the tilt images extracted from the airborne magnetic data. This is further supported by forward modeling of the magnetic and gravity data. (3) the Singo granite is characterized by relatively high and evenly-distributed equivalent concentration of Uranium (eU) and Thorium (eTh) compared to the surroundings and this is apparent in the Potassium (K)-eTh-eU radiometric ternary image. (4) the granitic body is defined by a gravity low anomaly that persisted to a depth of three km as shown by the Bouguer anomaly image and its five km upward continuation. We used these observations to identify this granitic body as a nested igneous ring complex and we refer to it as the Singo Igneous Ring Complex (SIRC). We further interpreted the eight ring structures as individual igneous ring complexes aligned in an E-W and NE-SW direction and these were developed due to repeated calderas collapse. Additionally, we interpreted the ring-shaped magnetic anomalies as due to hydrothermally-altered margins of the granite resulting from hot fluid circulation facilitated by 
the presence of concentric fracture zones that developed in association with the collapse of the calderas. We propose that the nested pattern of the SIRC was developed due to dominantly east and southwest migration of magma plumbing systems. Identifying the SIRC as a nested igneous ring complex has its importance in guiding future mineral exploration activities. Our study highlights the importance of high resolution geophysical data in mapping near surface igneous ring complexes, hence allowing for further examination of their magma plumbing systems. 


\section{Introduction}

The concept of caldera-related igneous ring complex was first introduced by Clough et al. (1909) for the district of Glen Coe of Scotland. Clough et al. (1909) described the term "cauldron" as a circular or oval shape eroded caldera defined by an inverted relief formed in association with subsidence guided by boundary faults. Since then numerous igneous ring complexes were discovered throughout the World and the majority of them are found as A-type alkaline anorogenic granites (Chappell and White, 1974). Igneous ring complexes are intruded within the upper crust; hence their preservation requires limited erosion since their emplacement. This might be the reason why they are often found as A-type anorogenic granites and not as Itype calc-alkaline orogenic granites within deeply-eroded ancient orogneic belts. This further explains the presence of some igneous ring complexes as I-type calc-alkaline orogenic granites within young mountainous orogenic belts such as the Coastal Batholith of Peru which is found within the Andes orogenic belt (Myers, 1975).

Emplacement of igneous ring complexes has occurred throughout the geological history of the Earth. For example, Black and Lameyre (1985) noted that one of the most striking features of the African continent is the presence of arrays of igneous ring complexes that range in age from 2000 to 25 Ma. Bowden (1985) concluded that the igneous ring complexes in Africa are petrographically variable but share common structural features in that they represent distinctive group of hypabyssal or sub-volcanic igneous intrusions constituting ring dikes and cone sheets. Some of these igneous ring complexes are found in clusters, hence referred to as migrating, overlapping, or nested igneous ring complexes (e.g. O’Hallordan, 1985; Bonin et al., 2004). 
The most popular explanation for the development of caldera-related igneous ring complexes with their distinct geometry and sub-volcanic igneous activities is the caldera collapse model (Bonin et al., 2004). This model advocates for an early phase that results in the "hydrofracturing" of the country rock because of the explosion of volatiles within an active magma chamber. Such an explosion results in the formation of dominantly circular to elliptical fracture zone that serves as conduit for the ascendance of magma with high concentration of vesicles filled with fluids. This leads to eruption of lava at the surface within a caldera through violent volcanic explosion. In the second phase, the extraction of magma from the magma chamber leads to caldera collapse characterized by down-ward subsidence of the crustal block underlying the caldera. Sinking of this crustal block into the magma chamber, that has already lost most of its volatile concentration during the first phase, leads to squeezing of the remaining magma in the magma chamber leading to emplacement of magmatic sheets at shallow depth beneath the collapsed caldera. Refilling of the magma chamber from a deeper magma source might lead to multiple repetition of this magma plumbing process.

Igneous activities associated with igneous ring complexes have significantly contributed to the growth of the continental crust (Johnson et al., 1999). The sub-volcanic-plutonic features, especially the ring-shaped dikes that typically surround the volcanic-sub-volcanic phase, in many cases are well-preserved making it feasible to establish the evolution of these systems in space and time. Hence, the study of igneous ring complexes has provided important information about the evolution of magma chambers and the way magma ascend through the upper crust (Johnson et al., 1999). Additionally, their study might provide important information about the crust and mantle dynamics at the time of their formation. In early studies, the deeper magma source that feeds the shallower magma plumbing system of the igneous ring complex is thought to be mantle 
plumes that might result in continental rift formation (Morgan, 1972; Gass et al., 1978). Differently, the presence of some A-type anorogenic granites that are found within Precambrian terranes is explained as due to melting of the lower crust that was previously thickened during the folding and thrusting that accompany the orogeny (Bonin, 2007). Such magmatism might accompany regional extension due to the gravitational collapse of the thickened crust. An alternative explanation for the deeper magma source is sub-continental lithospheric mantle delamination (Black and Liegeois, 1993; Avigad and Gvirtzman, 2009). Both Black and Liegeois (1993) and Avigad and Gvirtzman (2009) explained the presence of numerous A-type anorogenic granites in the Saharan Metacraton (Abdelsalam et al., 2002) and the northern part of the Arabian-Nubian Shield, respectively as due to melting of the lower crust when the subcontinental lithospheric mantle was removed leaving the asthenosphere to be in direct contact with the crust.

Igneous ring complexes are also important source of mineralization of rare metals. For example, Bowden et al. (1981) have shown that the source of uranium that was concentrated in the upper Paleozoic - lower Mesozoic sedimentary rocks in Niger was leaching of ignimbrites associated with some of the igneous ring complexes of the Niger-Nigeria younger granite suite. Also, Pastor and Turaki (1985) found that much of the placer tin and columbite mineralization mined in Nigeria was the weathering products of the Nigerian igneous ring complexes. Pastor and Turaki (1985) also found that the primary mineralization of tin and tungsten are disseminated cassiterite and columbite in biotite granite and quartz veins-controlled hydrothermal mineralization.

All studies that aimed at understanding the geometrical complexity of igneous ring complexes focused on the ones that are exposed to the surface. These studies relied on field 
mapping aided by remote sensing data and petrographic and geochemical analysis. Nonetheless, there might be numerous igneous ring complexes that are not exposed to the surface or they cannot be revealed as ring complexes from field mapping and petrography and geochemical studies alone. In this work we used high-resolution airborne magnetic and radiometric data and satellite gravity data to show for the first time that the Paleoproterozoic Singo granite in the Precambrian terranes of south-central Uganda is a nested igneous ring complex. Previous studies had identified the Singo granite as a single pluton. We used these data to outline the extent of individual ring complexes, used two-dimensional (2D) forward modeling of the airborne magnetic and satellite gravity data to establish the cross-sectional view of a selected igneous ring complex, and used cross-cutting relationship of the magnetic anomalies to suggest migration directions of the magmatic plumbing system that produced the Singo as a nested igneous ring complex. We further discuss our results within the context they provide for understanding controls on rare metals mineralization and planning for future exploration activities.

\section{Geology and Structure}

The Singo granite, referred to here as the Singo Igneous Ring Complex (SIRC), is part of the $\sim 1.85$ Ga Mubende-Singo suite which intrudes the 2.21 - 2.15 Rwenzori terrane (Figure 1). At the vicinity of the SIRC, the Rwenzori terrane constitutes the Nile Formation (shales, slates and phyllites), the Bujagali Volcanics (mafic metavolcanic rocks), and the Victoria Quartzites (ortho-quartzites and conglomerates). These are intruded by the $1.99-1.96 \mathrm{Ga}$ syn-tectonic granites and granitic gneisses of the Rukungiri Suite (Figures 2; Westerhof et al., 2014). In turn, these Paleoproterozoic rocks are overlain by the Paleoproterozoic Namuwasa Group 
(conglomerates and sandstones) which pre-dates the SIRC and the Bwezigoro Group (conglomerates and sandstones) that post-dates the SIRC (Figure 2; Westerhof et al., 2014). The Mubende-Singo suite consists of two intrusive bodies including the larger $\sim 3,000 \mathrm{~km}^{2}$ Mubende intrusion and the smaller $\sim 700 \mathrm{~km}^{2}$ Singo intrusion (Westerhof et al., 2014). Both are identified as post-kinematic intrusions and were emplaced after the main deformation events of the Rwenzori fold and thrust belt (Westerhof et al., 2014).

The SIRC was first described by King (1947), Johnson (1960), and Johnson and Williams (1961). Some of these early studies suggested that the SIRC was formed through metasomatic granitization rather than from crystallization of magma. For example, King (1947) concluded that "the granite never existed wholly as a magma or melt, but that it evolved as a series of replacements, effected by differential fixation in time and place of a succession of introduction from below and of materials displaced within the body itself". Further, some of these early studies did not report the presence of contact metamorphism that accompanied the emplacement of the granitic body. For example, Johnson (1960) concluded that the emplacement of the SIRC has very little effect on the country rocks. Differently, more recent studies have shown that the emplacement of the SIRC has resulted in contact metamorphism of the country rocks. Nagudi et al. (2003) have shown that the Paleoproterozoic shales, slates and phyllites of the Nile Formation surrounding the SIRC have undergone contact metamorphism resulting in the development of andalusite and/or cordierite-bearing hornfels.

Few studies have been carried out to determine the emplacement age of the MubendeSingo suite. The earliest of these age determination results are reported in Cahen and Snelling (1966) who obtained a whole-rock Rb-Sr age of 1807 +/- 60 Ma from the Mubende granite. Subsequently, Pinna et al. (2001) used U-Pb zircon evaporation analysis to determine the 
emplacement age of the SIRC as 1847 +/- 6 Ma. Differently, Nagudi et al. (2001) used the same $\mathrm{U}-\mathrm{Pb}$ zircon evaporation technique to report an age of $1615+/-19 \mathrm{Ma}$ for the emplacement of the SIRC, an age much younger than the emplacement age reported by Pinna et al. (2001). Nevertheless, the age of 1847 +/- 6 Ma obtained by Pinna et al. (2001) might be the more likely age for the emplacement of the SIRC. This is because recently Manttari (2014) obtained a crystallization age of $1848+/-6$ Ma from the Mubende granite using single zircon U-Pb MultiCollector - Laser Ablation - Induced Coupled Plasma - Mass Spectroscopy (MC-LA-ICP-MS) analysis and this age is almost identical to the one obtained by Pinna et al. (2001) for the SIRC.

Nagudi et al. (2003) suggested that the SIRC complex was crystallized from felsic magma formed from the melting of heterogeneous crustal source. Additionally, from modal composition analysis, Nagudi et al. (2003) identified the bulk composition of the SIRC to be mostly monzogranite with minor syenogranite composition. Further, Nagudi et al. (2003) suggested that the geochemical signature of the outer parts of the granitic body which are mostly biotite granite resembles those of S-type granites whereas the signature of the inner main phase of the SIRC which is mostly pink porphyritic granite is similar to those of I-type orogenic granites. However, Makitie et al. (2014) used geochemical discrimination diagrams to show that the tectonic affinity of the Mubende granite, which is magmatically related to the SIRC, is more of within-plate magmatism. This is in good agreement with the suggestion of Westerhof et al. (2014) that the emplacement of the Mubende-Singo suite might be related to crustal extension triggered by possible tectonic gravitational collapse following crustal thickening due to the Rwenzori orogenic event.

It has been shown that the margins of the SIRC have undergone sericitization and this has been attributed to post-emplacement hydrothermal activities (Westerhof et al. (2014). Westerhof 
et al. (2014) reported that, in some places, the granitic rocks at the margin of the SIRC have been altered to sericite-quartz greisen forming up to 70 meters wide linear zones which contain muscovite mica books and tungsten-bearing quartz veins. Additionally, Westerhof et al. (2014) concluded that these hydrothermal alteration zones are associated with shear zones which might have served as conduits for hot fluids circulation within the margins of the SIRC.

\section{Data and Methods}

\subsection{Airborne Magnetic Data}

The airborne magnetic data used in this study (Figure 3A) were part of a 2006-2009 data acquisition campaign by the Ugandan Department of Geological Survey and Mines (DGSM) that covered $80 \%$ of the country. The data were collected with a flight altitude of $\sim 80$ meters, line

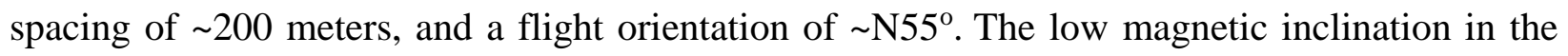
study area that ranges between $-14^{\circ}$ and $-22^{\circ}$ did not allow us to identify the sources of the magnetic anomalies using conventional methods such as reduction to pole. Alternatively, to highlight the extent and boundaries of individual intrusive bodies of the SIRC through the magnetic anomalies, we have extracted a horizontal derivative map from the total magnetic field data (Figure 3B). The results of this edge detection filtering technique are not affected by the magnetic inclination, declination or remanence (Thurston and Smith, 1997; Smith and Salem, 2005). Hence, we used the horizontal derivative map to image the edges of the magnetized bodies. The observed orientation of the resulting magnetic fabric (Figure 3B) acts as a proxy for mapping the margins of the intrusive bodies constituting the SIRC.

Additionally, to further highlight the margins of individual intrusive bodies of the SIRC, we have used the technique established by Thurston and Smith (1997), Verduzco et al. (2004), 
Smith and Salem (2005) and Salem et al. (2007) to develop tilt derivative images by obtaining the ratio between the vertical derivative and horizontal derivative of the total field magnetic data (Figures 4A and B). In these images, the tilt angle defines the contacts between geological materials that have alternating high and low magnetic susceptibilities (Salem et al., 2007). The calculated tilt angles range between $+90^{\circ}$ and $-90^{\circ}$ with the angle values with (+) sign represent the tilt of the magnetic source towards the northeast and southeast quadrants. The angle values with (-) sign indicate tilt direction towards the southwest and northwest quadrants.

\section{2. $\quad$ Airborne Radiometric Data}

The airborne radiometric data used in this study (Figure 5A) were simultaneously acquired with the airborne magnetic data and have the same data acquisition specifications. The emission of gamma rays through radioactive decay of naturally occurring radioisotopes has proven useful for mapping the boundaries of geological units (Duval, 1983; Minty, 1997). Hence, gamma ray surveys have been used to image the geochemical characteristics of the Earth surface and near surface to a depth of $30 \mathrm{~cm}$ (Erdi-Krausz et al., 2003). The three radioisotopes that have been traditionally used for geological mapping include Potassium (K), Uranium (U) and Thorium (Th). The emission of gamma rays during the decay of ${ }^{40} \mathrm{~K}$ to the stable isotope Argon $\left({ }^{40} \mathrm{Ar}\right)$ can be used to estimate the amount of $\mathrm{K}$ in the geological unit. Radioisotopes ${ }^{238} \mathrm{U}$ and ${ }^{235} \mathrm{U}$ decay to stable Lead isotope $\left({ }^{206} \mathrm{~Pb}\right)$ and $\left({ }^{207} \mathrm{~Pb}\right)$, respectively. The naturally occurring radioisotope ${ }^{232} \mathrm{Th}$ decay series ends in producing isotope ${ }^{208} \mathrm{~Pb}$. The concentration of radioisotopes ${ }^{238} \mathrm{U}$ and ${ }^{232} \mathrm{Th}$ in any geological unit can be indirectly estimated from the gamma ray emission of their radioactive daughter products. This is because these radioisotopes do not emit gamma ray in their initial radioactive decay process. Assuming that the radioactive daughter 
products of radioisotopes ${ }^{238} \mathrm{U}$ and ${ }^{232} \mathrm{Th}$ are under equilibrium, the concentration of the two radioisotopes can be estimated as the equivalents $\mathrm{eU}$ and $\mathrm{eTh}$ in parts per million (ppm).

After removing the noise from the airborne radiometric data using the noise-adjusted value decomposition method, we used the minimum curvature gridding algorithm (Briggs, 1974; Grasty, 1997; Minty and McFadden, 1998) to obtain K, eTh, and eU concentrations from the airborne radiometric data with a grid cell spatial resolution of $50 \mathrm{~m}$. Subsequently, we created a ternary image by assigning the $\mathrm{K}$ concentration to cyan, the eTh concentration to magenta, and the eU concentration to yellow (Figure 5A). Areas with high concentration in all three radioisotopes appear black in the ternary image. Differently, areas that lack concentration of all radioisotopes appear white as in the case of water bodies. The color blue in the ternary image is indicative of high $\mathrm{K}$ and Th concentration, green reflects high concentration of $\mathrm{K}$ and $\mathrm{U}$, whereas red manifests high Th and $\mathrm{U}$ concentration.

To highlight in a single image the radioisotope concentrations as well as the magnetic susceptibility of different lithological units, we have generated a fused radiometric-magnetic ternary image by assigning the concentration of radioisotope $\mathrm{K}$ to cyan, eTh to magenta and the total magnetic intensity (TMI) to yellow (Figure 5B). In this image, the color cyan represents geological material with high $\mathrm{K}$ concentration but low eTh concentration and low TMI, cyan reflects regions dominated by geological materials that have high eTh concentration but low $\mathrm{K}$ concentrations and low TMI, and yellow represents materials with high TMI but low K and eTh concentrations. The color black is indicative of high $\mathrm{K}$ and Th concentration as well as high TMI. Areas highlighted with white color are likely dominated by geological materials that have low $\mathrm{K}$ and eTh concentration as well as low TMI. The color green in this image indicates high $\mathrm{K}$ concentration and high TMI, the color red highlight regions with high eTh concentration and 
high TMI, whereas the color blue indicates the presence of geological materials that have high $\mathrm{K}$ and eTh concentrations but have low TMI.

\subsection{World Gravity Map (WGM2012) Satellite Gravity Data}

The satellite gravity data used in this study (Figure 6A) is a product of the World Gravity Map (WGM2012) computed from the Earth Spherical Model (EGM 2008) instead of the conventional Bouguer slab correction (Balmino et al., 2012; Bonvalot et al., 2012) and have a spatial resolution of $\sim 9 \mathrm{~km}$. These data were compiled by the Bureau Gravimetrique International (BGI) with the support of the United Nations Educational Scientific and Cultural Organization (UNESCO) in association with the International Gravity Field Services (IFGS). The WGM2012 data are based on the Earth Gravity Model (EGM2008) which is a compilation of all available land, sea, airborne and any other regional gravity databases (Balmino et al., 2012; Bonvalot et al., 2012).

We also carried out an upward continuation of the Bouguer anomaly of the WGM2012 data to a depth of $5 \mathrm{~km}$ to attenuate the influence of short wavelength anomalies due to shallow sources, thus enhancing significantly the signatures from deeper sources (Figure 6B).

\subsection{Two-dimensional (2D) Modeling of Aeromagnetic and Satellite Gravity Data.}

To examine the sub-surface cross-sectional view and the three-dimensional (3D) structure of the SIRC, we have developed 2D forward models for a NW-SE profile across the granitic body (See figures 3A and 6A for the location of the profile). When applicable, we have used in situ susceptibility and density measurements for different geological units published in (Ruotoistenmäki and Birungi 2014). The magnetic susceptibility data published in 
(Ruotoistenmäki and Birungi 2014) were acquired on different rock samples using the hand-held susceptibility meter SM-20 with a sensitivity of $1 \times 10^{-4}$ SI and these values represent an average of three measurements from each rock sample. The density values published in (Ruotoistenmäki and Birungi 2014) were obtained using standard procedure of weighing rock samples in air and water using weighing scale with an accuracy of $\sim 1 \mathrm{gm}$.

Using the 2D-GMsys program we have created 2D forward models for the NW-SE profiles extracted from the airborne magnetic and WGM2012 satellite gravity data that crosses the central part of the SIRC (Figures 3A, 6A and 7A and B). For this we have established polygons representing four different geological units with different susceptibilities and densities. These are: (1) the shales, slates and phyllites of the Paleoproterozoic Nile Formation within which the SIRC was intruded. We assigned a susceptibility value $3.0 \times 10^{-4} \mathrm{SI}$ and a density value of $2.63 \mathrm{gm} / \mathrm{cm}^{3}$ for this geological unit. (2) the unaltered Paleoproterozoic granite that dominates the central parts of the SIRC. We assigned a susceptibility value of $3.0 \times 10^{-4}$ SI and a density value of $2.65 \mathrm{gm} / \mathrm{cm}^{3}$ for this geological unit. (3) a hydrothermally-altered granitic unit occupying the rim of the SIRC. We have assigned susceptibility values of $3.1 \times 10^{-4}$ SI for the northwestern margin and $3.5 \times 10^{-4}$ SI for the southeastern margin of the SIRC. Additionally, we have assigned a uniform density value of $2.66 \mathrm{gm} / \mathrm{cm}^{3}$ for this unit. (4) an overburden constituting laterites and lateritized weathered bedrock and we assigned a susceptibility value of $5.0 \times 10^{-4} \mathrm{SI}$ and a density of $2.40 \mathrm{gm} / \mathrm{cm}^{3}$ to this unit.

The susceptibility and density values we used in the 2D forward modeling of airborne magnetic and WGM2012 satellite gravity data, besides being constrained by in situ petrophysical measurements (Ruotoistenmäki and Birungi 2015), are also in good agreement with geological and geophysical observations: (1) the presence of hydrothermally-altered granites at the margins 
of the SIRC that are expected to have higher susceptibility and density values compared to the unaltered granites have been documented from previous field studies (Westerhof et al., 2014). (2) in our 2D forward modeling we used susceptibility values for the hydrothermally-altered margins of the SIRC that are higher $\left(3.1 \times 10^{-4} \mathrm{SI}\right.$ and $\left.3.6 \times 10^{-4} \mathrm{SI}\right)$ than the surrounding rocks of the Nile Formation $\left(3.0 \times 10^{-4} \mathrm{SI}\right)$. Also, we used higher susceptibility values for the rocks of the Nile Formations compared to the unaltered granites at the core of the SIRC $\left(2.8 \times 10^{-4} \mathrm{SI}\right)$. This is in good agreement with the observed total magnetic intensities of these rocks units where the margins of the SIRC is shown to have higher magnetization compared to the rocks of the Nile formation which in turn appear to have higher nT counts compared to the granites at the core of SIRC (Figure 3A). (3) in our 2D forward modeling we used higher susceptibility value $\left(3.6 \times 10^{-4}\right.$ $\mathrm{SI})$ for the southeastern margin of the SIRC compared to its northwestern margin $\left(3.1 \times 10^{-4} \mathrm{SI}\right)$. This is in good agreement with the observed total magnetic intensity where the southeastern margin of the SIRC appears to have higher magnetization compared to its northwestern margin (Figure 3A). (4) in our 2D forward modeling we introduced an overburden layer constituting laterites and lateritized bedrock that have higher susceptibility $\left(5.0 \times 10^{-4} \mathrm{SI}\right)$ but lower density (2.4 $\left.\mathrm{gm} / \mathrm{cm}^{3}\right)$ compared to the bedrock units. Thick horizons of laterites and outcrops of lateritized Precambrian bedrocks are common features of the region within and around the SIRC (Westerhof et al., 2014).

\section{Results}

\subsection{Geophysical characteristics and extent of the Singo Igneous Ring Complex (SIRC)}

4.1.1. Airborne magnetic data: Both the total field magnetic image (Figure 3A) and the horizontal derivative image show the SIRC as a curved feature that extends in a NE-SW direction for $\sim 60 \mathrm{~km}$ with a maximum width of $\sim 15 \mathrm{~km}$ at its center. This is bound by festoon- 
shaped margins characterized by high magnetization reaching over $100 \mathrm{nT}$ in the southeastern margin of the SIRC (Figure 3). The margin with high magnetization becomes almost circular $(\sim 7$ $\mathrm{km}$ in diameter) at the southwestern end of the SIRC and this body has been previously described as a satellite granitic intrusion of the SIRG (Westerhof et al., 2014). A circular margin with similar high magnetization and dimension can be found in the northern part of the SIRC and this margin is better defined in the horizontal derivative image (Figure 3B). These high magnetization margins enclose cores that are characterized by significantly lower magnetization reaching in some places less than $-600 \mathrm{nT}$ (Figure 3A). The region surrounding the SIRC which is dominated by the shales, slates and phyllites of the Paleoproterozoic Nile Formation (Figure 2) shows varying magnetization that are generally lower than those of the margin of the SIRC, but higher that its center except in the north where a region with the highest magnetization outside the SIRC is encountered (Figure 3A). Both the total magnetic field image (Figure 3A) and the horizontal derivative image (Figure 3B) show that the SIRC is dissected by NW-trending linear magnetic anomaly features which appear with generally low magnetization in the total magnetic field image but with closely-spaced low and high magnetic lineation in the horizontal derivative image (Figure 3B). These were interpreted by Ruotoistenmäki (2014) together with similar features in Tanzania as inward dipping, cone-like concentric ring dikes formed possibly above a mantle plume after the emplacement of the SIRC.

The filtered positive and negative tilt images extracted from the airborne magnetic data suggest that the margins of the SIRC are steep. In the positive tilt image, the southern margin of the SIRC is shown with an anomaly that averages $\sim 60^{\circ}$ whereas no anomaly is observed on the northwestern margin of the SIRC where this margin is highlighted with white color (Figure 4A). Differently, discontinuous anomalies averaging $\sim 70^{\circ}$ are observed in the negative tilt image in 
the northwestern margin of the SIRC but no anomalies are observed in its southeastern margin as indicated by the domination of white color (Figure 4B). The anomaly patterns in the tilt images suggest outward dipping of the margins of the SRIC.

4.1.2. Airborne radiometric data: The K-eTh-eU radiometric ternary image dominantly highlight the SIRC with either red or black color with the exception of its southwestern part where the margin of the circular body is shown as red whereas the core of the feature is shown as green (Figure 5A). This indicate that the SIRC has either high concentration in all three radioisotopes or high concentration of only eTh and eU expect the southwestern body where it is possible that its core has high concentration of $\mathrm{K}$ and $\mathrm{eU}$. The radiometric signature of the SIRC is different from those of the surrounding Precambrian rock units except the outcrops of other granitic bodies notably the granites and granitic gneisses of the Rukungiri suite and the Mubende granite west of the SIRC (Compare figures 2 and 5A). Rocks of other Precambrian units surrounding the SIRC are shown with a spectrum of cyan to blue colors reflecting varying concentrations of $\mathrm{K}$ and eTh. The Mesoproterozoic Mityana Group to the south of the SIRC which constitutes conglomerates and sandstones is an exception where the ternary radiometric image suggests high concentration of $\mathrm{eTh}$ and $\mathrm{eU}$ in this unit as indicated by the domination of the red color (Compare figures 2 and 5A). This unit post-dates and is separated by an unconformity from the SIRC (Westerhof et al., 2014). It is possible that part of the material constituting the sedimentary rocks of the Mityana Group represent weathering products of the SIRC, hence the similarity in the radiometric signature of the two rock units. 
Different from the airborne magnetic images, the radiometric ternary image does not show significant difference between the margins and the central parts of the SIRC. This suggest that there was no initial difference between the margins and the central parts of the SIRC in the concentration of the radioisotopes at the time of crystallization or subsequent enrichment or leaching of any of the radioisotopes during post-crystallization hydrothermal activities. Rather, the hydrothermal activities might have resulted in the concentration of geological materials such as rare metals that are non-radiogenic but have high susceptibility. This notion is generally supported by the fused radiometric-magnetic ternary image where the margins of the SIRC are marked with black to green anomalies different from the surrounding Precambrian rocks (Figure 5B). This indicates either higher concentration of $\mathrm{K}$ and $\mathrm{eTh}$ as well as higher TMI or higher concentration of $\mathrm{K}$ and higher TMI.

4.1.3. Satellite gravity data: The Bouguer anomaly of the WGM2012 satellite gravity data depicts the SIRC as a gravity low anomaly surrounded by gravity high anomaly (Figure 6A). This gravity low anomaly reaches close to $35 \mathrm{mGal}$ and persists to a depth of $\sim 3 \mathrm{~km}$ as shown by the $5 \mathrm{~km}$ upward continuation of the Bouguer anomaly data (Figure 6B). This depth is consistent with the depth continuation of sub-volcanic intrusions of other igneous ring complexes (Bonin, 2007). At this depth the SIRC is characterized by a single gravity low anomaly compared to the surface Bouguer anomaly where discrete gravity anomalies can be identified (Figure 6A). 


\subsection{Depth extent of the Singo Igneous Ring Complex (SIRC)}

The 2D forward modeling of the airborne magnetic and satellite gravity data suggest the presence of steep, 4 to $5 \mathrm{~km}$ wide bodies with higher magnetic susceptibility $\left(3.1 \times 10^{-4} \mathrm{SI}\right)$ and density $\left(2.66 \mathrm{gm} / \mathrm{cm}^{3}\right)$ compared to the core they surround (Figure 7$)$. These bodies persisted to a depth of at least 3 to $4 \mathrm{~km}$. We interpret these bodies as the hydrothermally-altered margins of the SIRC (Figure 7). In this regard, these hydrothermally-altered margins represent the margins of the sub-volcanic intrusions which were crystallized beneath the volcanic caldera. The hydrothermal alteration was facilitated by the development of concentric faults when the volcanic caldera collapsed. It is possible that ring dikes that were intruded within the country rocks are presented at depth greater that $5 \mathrm{~km}$ as suggested by thermo-barometric studies (Bonin, 2007).

\section{Discussion}

\subsection{Nested geometry and migration direction of the Singo Igneous Ring Complex (SIRC)}

Interpretation of the airborne magnetic data suggests that the SIRC is made-up of eight almost circular nested igneous ring complexes (Figure 8A). These are aligned in an E-W and NE-SW direction, possibly due to magma supply of the sub-volcanic intrusions through magma plumbing systems that migrated eastward and southeastward. These rings are defined by high magnetization suggesting the enrichment of ferromagnetic minerals probably through hydrothermal fluids as previously suggested by Westerhof et al. (2014). Generally, the three northeastern complexes are aligned in an E-W direction whereas the four southwestern ring complexes are aligned in a NE-SW direction (Figure 8A). The size of the E-W aligned ring complexes decreased from west to east from $\sim 12 \mathrm{~km}$ in diameter (ring 2 in Figure $8 \mathrm{~A}$ ) to $10 \mathrm{~km}$ 
(ring 3) to $\sim 6 \mathrm{~km}$ (ring 4). No particular direction of decrease in the size is observed in the NESW aligned ring complexes (Figure 8A). Rather, the two northeastern igneous ring complexes (rings 1 and 2) are $\sim 15-12 \mathrm{~km}$ in diameter whereas the southeastern-most complex (ring 3 ) is $\sim 7$ $\mathrm{km}$ in diameter. In between is a $\sim 5 \mathrm{~km}$ in diameter ring complex (ring 3 in Figure 8A). The E-W and NE-SE alignment pattern of the individual ring complexes of the SIRC is interrupted by a $\sim 7$ $\mathrm{km}$ in diameter ring complex that occupied the region where the change in the alignment directions occurred (ring 4 in Figure 8A).

Worldwide there are many examples of nested igneous ring complexes that were formed in different geological times. In Africa such examples include the Taourirt magmatic provide in Algeria that was emplaced within the northern part of the Tuareg Shield between 540 and 520 Ma marking the final stages of the Pan-African orogey that resulted in the amalgamation of tectonic terranes during the Neoproterozoic times (Azzouni-Sekkal et al., 2003). Another example of a nested igneous ring complex in Africa is found in the southern part of the Tuareg Shield represented by the 480-400 Ma old Aïr granite province in Niger (Black et al., 1985; Moreau et al., 1994). The emplacement of both the Taourirt magmatic province and the Aïr granite province is thought to be controlled by Precambrian lithospheric-scale shear zones. One of the examples in which the migration direction of the nested igneous ring complex is clearly preserved in found in northern Sudan in the Bayuda desert which represents part of the eastern margin of the Saharan Metacraton (Abdelsalam et al., 2002). In this Paleoproterozoic terrane which was remobilized during the Neoproterozoic a number of $~ 240$ Ma old igneous ring complexes are found overlapping and their cross-cutting relationship together with progressive decrease in diameter indicate the migration of the magma plumbing system from west to east (O’Halloran, 1985). 
Based on the interpretation of cross-cutting relationship between circular features representing individual ring complexes apparent in the airborne magnetic images, we suggest that the magma plumbing system resulted in the formation of the nested SIRC might have migrated in three different directions (Figure 8A). The E-W aligned ring complex magma plumbing system might have migrated in an east direction whereas the NE-SW aligned ring complexes magma plumbing system might have migrated in a southwest direction. The offaligned igneous ring complex suggests a migration of the magma plumbing system in a north direction. It is not clear from the cross-cutting relationship whether the migration of the magma plumbing system in these three different directions occurred concurrently or at different times.

To explain the formation of the SIRC as a nested igneous ring complex with possible northward, eastward, and southwestward migration we propose a five-step model that involves repeated calderas collapse due to magma extraction from magma chambers that occurred at depth ranging between 10 and $20 \mathrm{~km}$ (Figures 8B-F). This is followed by the emplacement of sub-volcanic plutonic sheets and ring dikes as well as the formation of ring fractures (Figure 8BF) that facilitated the percolation of hydrothermal fluids at the margins of the sub-volcanic plutonic sheets. We suggest that the formation of the SIRC started from a central magma plumbing system (Figure 8A) and migrated eastward and southeastward when the central magma chamber became inactive (Figure 8B). The eastward and southwestward migration of the magma plumbing system continued when the magma chambers immediately surrounding the central magma chambers became inactive (Figure 8D). Finally, the magma plumbing systems migrated eastward and southwestward as well as northward (Figure 8E) and the crystallization of the magma chambers associated with the outermost magma plumbing systems ultimately resulted in the formation of the SIRC as a nested ring complex. 
It has been suggested that localized shear zones at the margins of the SIRC have facilitated the peculation of hydrothermal fluids leading to widespread sericitization (Westerhof et al., 2014). However, the overall E-W and NE-SW alignment of the SIRC doesn't seem to be controlled by the observed pre-existing structures. Extraction of regional structural trends from the airborne magnetic data, especially the positive and negative tilt images (Figure 4) shows that the SIRC cut across regional fabric that changes orientation to depict what appears to be an open NE-SW trending folding structure (Figures 2 and 8A). This observation is supported by the findings of Nagudi et al. (2003) who observed that the SIRC occurs within a syncline and that its contacts are discordant to the regional fabric of the Precambrian units within which it was emplaced.

It has been shown from field observations and analogue modeling that the emplacement of magma in the upper-most crustal level can be influenced by secondary structures that are at oblique orientation to the major deeper structures. For example, Pasquare and Tibaldi (2003) found that the lava domes comprising the Bicol volcanic arc in the Philippines are aligned in a NE-SW direction, perpendicular to the NW-trending Philippine fault system. Pasquare and Tibaldi (2003) suggested from the analysis of apical grabens within the lava domes and structural data constrained analogue model that magma that fed the Bicol volcanic arc rose at depth guided by NW-trending fractures associated with the Philippine fault system. Pasquare and Tibaldi (2003) subsequently suggested that the alignment of the lava domes in a NE-SW direction was due to the emplacement of the magma in the upper-most crust along secondary NE-trending fracture system. Hence, it is possible that the overall alignment of the SIRC in E-W and NE-SW direction is not representative of the trend of deeper structures (such as lithospheric-scale shear zone) that served as conduits for the magma ascendance. 


\subsection{The Singo Igneous Ring Complex (SIRC) and Mineral Exploration}

Igneous ring complexes can be important economic sources for rare metals either when hosting primary mineralization zones or through secondary mineral concentration of their weathering products in the form of placer deposits. In Africa, this is best exemplified by the presence of economic gold and tungsten deposits associated with the Niger-Nigeria younger granite suite (Bowden et al., 1981; Paster and Turaki, 1985). Hence, the SIRC and surroundings can potentially be important sources for rare metals including tungsten, gold and uranium.

The potential of SIRC for finding economic mineral deposits has been highlighted in a recent publication by Lehto and Katto (2014) who reported gold mineralization around the SIRC within the Paleoproterozoic basement rocks and tungsten mineralization at the margins of the SIRC (Figure 2) and some of these represent economic deposits that are currently being mined. Leho and Katt (2014) have shown that the gold mineralization is found hosted by hematitequartz veins intruding the shales and sandstones of the Paleoproterozoic Buganda Group, the exposed part of it around the SIRC is represented by the Nile Formation (Figure 2). Lehto and Katto (2014) further explained the genesis of the mineralization in terms of remobilization of the gold from mafic volcanic rocks that underlie the shales and sandstones of the Buganda Group due to heating resulting from the intrusion of the SIRC. Lehto and Katto (2014) also reported gold mining activities within the unconsolidated alluvium deposits at the margin of the SIRC.

Lehto and Katto (2014) also reported the presence of tungsten deposits at the margins of the SIRC, especially in its southwestern part (Figure 2). Leho and Katt (2014) reported that the tungsten mineralization is found within tourmaline quartz pegmatites within the margins of the SIRC which is dominated by coarse-grained non-deformed granite that might be a younger intrusive phase compared to the finer-grained granite at the center of the SRIC. Additionally, 
Lehto and Katto (2014) reported the presence of wolframite deposits within a setting similar to the tungsten and suggested that the mineral concentration might be associated with greisen-type processes. Hence, we suggest that identifying the SIRC as a nested ring complex will help guide future mineral exploration activities by focusing on the zones that represent the nested ring structures since these are the most likely to host tungsten and wolframite deposits.

Lehto and Katot (2014) reported that the SIRC has a relatively high (compared to other A-type anorogenic granites) but uniform distribution of uranium concentration, hence it is unlikely that the SIRC hosts economic uranium mineralization. We point to the possibility that the SIRC might have been a source of uranium mineralization through secondary enrichment. It is possible that the SIRC was the provenance of the sediments that were deposited within the Mesoproterozoic Mityana Group which shows radiometric signature similar to the SIRC (Figures 2 and 5). Such weathering-deposition processes might result in the concentration of uranium to an economic level. This is best exemplified by the economic uranium deposits of the Niger where the deposits are found within upper Paleozoic - lower Mesozoic sedimentary rocks sourced from the leaching of ignimbrites associated with igneous ring complexes of the NigerNigeria younger granite suite (Bowden et al., 1981).

It is also possible that secondary concentration of uranium through the weathering of the SIRC might be found within the alluvium sediments surrounding it. This alluvium might have undergone additional leaching as indicated by the presence of extensive laterite and kaolin deposits (Lehto and Katto (2014). Additionally, the leaching processes might have occurred in a long period of time since the alluvium sediments were deposits in a rather old surface and that the SIRC was exposed to the surface for a long period of time. The presence of the 
Paleoproterozoic Bwezingoro group which unconformably overlie the SIRC indicate that it has been exposed to the surface since the Paleoproterozoic time (De Kock and Natukunda, 2014).

\section{Conclusions}

Analysis of airborne magnetic and radiometric data and satellite gravity data allowed us to show that the Paleoproterozoic Singo granite, which intrudes the Paleoproterozoic basement rocks of the Rwenzori terrane and unconformably overlain by the sedimentary rocks of the Rwenzuri terrane in south-central Uganda as a nested igneous ring complex, termed here the Singo Igneous Ring Complex (SIRC). The SIRC is characterized by distinct geophysical signatures in the form of high magnetic anomalies at its margins, relatively elevated and uniform eTh and eU concentration, and low gravity anomaly. The SIRC was formed because of repeated calderas collapse that initiated circular fracture zones allowing for upward migration of hot fluids, hence resulting in hydrothermal alteration of the margins of discrete granitic bodies producing the apparent high anomalies in the airborne magnetic images. The SIRC is made-up of eight individual ring complexes that are aligned in an E-W and NE-SW direction due to the magma supply of the sub-volcanic intrusions through magmatic plumbing systems that migrated east and southwest. Identifying the SIRC as an igneous ring complex has the potential for guiding future mineral exploration in the region through, for example, focusing on the ring structures defined by the high magnetic anomaly for finding additional economic tungsten deposits. We suggest that, although currently not fully explored, the highly magnetized edges of the SIRC represent potential areas for mineral extraction similar to other igneous ring complexes Worldwide. 


\section{Acknowledgements}

We thank the Government of Uganda for allowing us free access to the airborne magnetic and radiometric data. This study was partially financially supported by the National Science Foundation - Continental Dynamics grant \# EAR 1255233. We thank J.P. Liégeois for constructive review and Editor R. Mapeo for handling the manuscript. This is Oklahoma State University Boone Pickens School of Geology contribution number 2015- 25. 


\section{References}

Abdelsalam, M.G., Liégeois J.P., Stern, R.J. 2002. The Saharan Metacraton, Journal of African Earth Sciences 34, 119-136.

Avigad, D., Gvirtzman, Z., 2009. Late Neoproterozoic rise and fall of the northern ArabianNubian Shield: The role of lithospheric mantle delamination and subsequent thermal subsidence. Tectonophysics 477, 217-228.

Azzouni-Sekkal, A., Liegeois, J-P., Bechiri-Benmerzoug, F., Belaidi-Zinet, S., Bonin, B. 2003. The "Taourirt" magmatic province, a marker of the closing stage of the Pan-African orogeny in the Tuareg Shield: review of available data and Sr-Nd isotope evidence. Journal of African Earth Sciences 37, 331-350.

Balmino, G., Vales, N., Bonvalot, S., Briais, A. 2012. Spherical harmonic modelling to ultrahigh degree of Bouguer and isostatic anomalies. Journal of Geodesy 86, 499-520.

Black, R., and Lameyre, J. 1985. The structural setting of alkaline complexes. Journal of African Earth Sciences 3, 5-16.

Black, R., Liégeois, J.P., 1993. Cratons, mobile belts, alkaline rocks and continental lithospheric mantle: the Pan-African testimony. Journal of the Geological Society of London 150, 8998.

Bonin, B. 2007. A-type granites and related rocks: Evolution of a concept, problems and prospects. Lithos 97, 1-29. 
Bonin, B., Ethien, R., Gerbe, M.C., Cottin, J.Y., Feraud, G., Gagnevin, D., Giret, A., Michon, G., and Moine, B. 2004. The Neogene to Recent Rallier-du-Baty nested ring complex, Kerguelen Archipelago (TAAF, Indian Ocean: stratigraphy revisited, implication for cauldron subsidence mechanisms. Geological Society of London Special Publications 234, 125-149.

Bonvalot, S., Balmino, G., Briais, A., M. Kuhn, Peyrefitte, A., Vales, Biancale, R., Gabalda, G., Moreaux, G., Reinquin, F., Sarraillh, M. 2012. World Gravity Map, 1:50,000,000. Editors: Bureau Gravimetrique International (BGI) - Commission for the Geological Map of the World (CGMW), Centre National d'Etudes Spatiales (CNES) - Institut de Reserche pour le Development (IRD), Paris.

Bowden, P. 1985. The geochemistry and mineralization of alkaline ring complexes in Africa (a review). Journal of African Earth Sciences 3, 17-39.

Bowden, P., Bennett, J.N., Kinnaird, J.A., Whitley, J.E., Abaa, S.I., and HadzigeorgiouStavrakis, P.K. 1981. Uranium in the Niger-Nigeria Younger Granite Province. Mineralogical Magazine 44, 379-389.

Briggs, I.C., 1974. Machine contouring using minimum curvature. Geophysics 39, 39-48.

Cahen, L., Snelling, N.J. 1966. The geochronology of equatorial Africa. North-Holland Publication Company, Amsterdam. 195p.

Chappel, B.W., White A.J.R. 1974. Two contrasting granite types. Pacific Geology 8, 173-174.

Clough, C.T., Maufe, H.B., and Bailey, E.B. 1090. Yje cauldron-subsidence of Glen Coe and the associated igneous phenomena. Geological Society of London Quarterly Journal 65, 611678. 
De Kock, G., and Natukunda, J. 2014. The Namuwasa and Bwezigoro groups and Kyato dolerite remnants south of Kiboga, Uganda: Lithology and ages. Geological Survey of Finland Special Paper 56, 273-293.

Duval, J., 1983. Composite color images of aerial gamma-ray spectrometric data. Geophysics 48, $722-735$.

Erdi-Krausz, G., Matolin, M., Minty, B., Nicolet, J.-P., Reford, W.S., Schetselaar, E., 2003. Guidelines for radioelement mapping using gamma-ray spectrometry data. International Atomic Energy Agency Publication IAEA-TECDOC-1363, Vienna, Austria, 173 p.

Gass, I.G., Chapman, D.S., Pollack, H.N., Thorpe, R.S. 1978. Geological and geophysical parameters of mid-plate volcanism. Philisophical Transactions of the Royal Society of London 288A, 581-597.

Grasty, R.L., 1997. Radon emanation and soil moisture effects on airborne gamma-ray measurements. Geophysics 62, 1379-1385.

Johnson, R.J. 1960. Explanation of the geology of sheet 69 (Lake Wamala). Geological Survey of Uganda Report Number 3, Entebbe, Uganda, 35p.

Johnson, R.J., and Williams, C.E.F. 1961. Explanation of the geology of sheet 59 (Kiboga). Geological Survey of Uganda Report Number 7, Entebbe, Uganda, 39p.

Johnson, S.E., Paterson, S.R., and Tate, M.C. 1999. Structure and emplacement history of a multiple-center, cone-sheet-bearing ring complex: The Zarza Intrusive Complex, Baja California, Mexico. Geological Society of America Bulletin 111, 607-619.

King, B.C. 1947. The textural features of the granites and invaded rocks of the Singo batholith of Uganda and their petrogenetic significance. Geological Society of London Quarterly Journal 102, 37-64. 
Lehto, T., Katto, E. 2014. Mineral resources of Uganda. Geological Survey of Finland Special Paper 56, 165-231.

Manttari, I. 2014. Mesoarchaean to Neoproterozoic crustal evolution of Uganda: Evidence from new U-Pb and Sm-Nd rock ages. Geological Survey of Finland Special Paper 56, 121164.

Manttari, I., Harma, P., Virransalo, P., de Kock, G., Lugaizi, I., Tumwine, A. 2014. The granite batholith of Mubende, Uganda: Preliminary results on its petrography, geochemistry and construction rock potential. Geological Survey of Finland Special Paper 56, 251-272.

Minty, B., 1997. Fundamentals of airborne gamma-ray spectrometry. AGSO Journal of Australian Geology and Geophysics 17, 39-50.

Minty, B., McFadden, P., 1998. Improved Noise adjusted singular deconvolution (NASVD) smoothing of airborne gamma-ray spectra. Exploration Geophysics 29, 516-523.

Moreau, C., Demaiffe, D., Bellion, Y., Boullier, A-M. 1994. A tectonic model for the location Palaeozoic ring complexes in Air (Niger, West Africa). Tectonophysics 234, 129-146.

Morgan, W.J. 1972. Plate motions and deep mantle convection Memoir of the Geological Society of America 132, 7-22.

Myers, J.S. 1975. Cauldron subsidence and fluidization: Mechanisms of intrusion of the Coastal Batholith of Peru into ints own volcanic ejecta. Geological Society of America Bulletin $86,1209-1220$. 
Nagudi, B., Koeberl, C., Klotzli, U. 2001. Determination of the petrographic history and age of the Singo granite unsing zircons. In: Schumann, A., Muwanga, A., Tiberindwa, J.V., and Owor, M. (eds.). Abstract volume of the Geological Society of Uganda and Geological Society of Africa regional conference on "Basement Geology, Groundwater, Mineral Resources and Mining related Environmental Problem in Eastern Africa, Kampala, Uganda, 36-37.

Nagudi, B., Koeberl, C., and Kurat, G. 2003. Petrography and geochemistry of the Singo granite, Uganda and implications for its origin. Journal of African Earth Sciences 36, 73-87.

O’Halloran, D.A. 1985. Ras ed Dom migrating ring complex: A-type granites and syenites from the Bayuda Desert, Sudan. Journal of African Earth Sciences 3, 61-75.

Pasquare, F.A., and Tibaldi, A. 2003. Do transcurrent faults quide volcano growth? The case of NW Bicol Volcanic Arc, Luzon, Philippines. Terra Nova 15, 204-212.

Pastor, J., and Turaki, U.M. 1985. Primary mineralization in Nigerian ring complexes and its economic significance. Journal of African Earth Sciences 3, 223-227.

Pinna, P., Cocherie, A., Thieblemont, D. 2001. New data on the (Archean?) Buganda Group, Uganda. In: Schumann, A., Muwanga, A., Tiberindwa, J.V., and Owor, M. (eds.). Abstract volume of the Geological Society of Uganda and Geological Society of Africa regional conference on "Basement Geology, Groundwater, Mineral Resources and Mining related Environmental Problem in Eastern Africa, Kampala, Uganda, 41-42.

Ruotoistenmäki, T., 2014. Geophysical characteristics of Aswa shear, Nakasongola discontinuity and ring dyke complex in Uganda. Journal of African Earth Sciences 93, 23-41.

Ruotoistenmaki, T., Birungi, N.R. 2015. Petophysical database of Uganda. Journal of African Earth Sciences 106, 17-39. 
Salem, A., Williams, S., Fairhead, J.D., Ravat, D., Smith, R., 2007. Tilt-depth method: A simple depth estimation method using first-order magnetic derivatives. The Leading Edge 26, $1502-1505$.

Smith, R.S., Salem, A., 2005. Imaging depth, structure, and susceptibility from magnetic data: The advanced source-parameter imaging method. Geophysics 70, 31-38.

Thurston, J., Smith, R., 1997. Automatic conversion of magnetic data to depth, dip, and susceptibility contrast using the Source parameter imaging method. Geophysics 62, 807813.

Verduzco, B., J. D. Fairhead, C. M. Green, C. MacKenzie, 2004, New insights into magnetic derivatives for structural mapping: The Leading Edge 23, 116-119.

Westerhof, A.B.P., Harma, P., Isabirye, E., Katto, E., Koistinen, T., Kuosmanen, E., Lehto, T., M.I. Lehtonen, M.I., Makitie, H., Manninen, T., Manttari, I., Pekkala, Y., Pkki, J., Saalmann, K., Virransalo, P., 2014. Geology and geodynamic development of Uganda with explanation of the 1:1,000,000 scale geological map. Geological Survey of Finland Special Paper 55, 387p. 


\section{Figure Caption}

Figure 1: (A) Location of Uganda within the African continent. (B) Simplified geological map of Uganda showing the geographic extent of Precambrian terranes and post-Precambrian volcanic and sedimentary rocks. Modified after Westerhof et al. (2014).

Figure 2: Geological map of the Singo granite and surroundings. Modified after Westerhof et al. (2014). Trends of the Precambrian regional fabric are extracted from the interpretation of airborne magnetic data. Black circles with the letter " $G$ " and "W" inside then show location of known gold and tungsten mineral concentrations, respectively.

Figure 3: Airborne magnetic images of the Singo granite and surroundings. (A) Total magnetic field intensity image. (B) Horizontal derivative image of the total magnetic field intensity data.

Figure 4: Airborne magnetic images of the Singo granite and surroundings. (A) Positive tilt image of the total magnetic field intensity data. (B) Negative tilt image of the total magnetic field intensity data.

Figure 5: Airborne radiometric and magnetic images of the Singo granite and surroundings. (A) Potassium (K) - Thorium (eTh) - Uranium (eU) ternary radiometric map. (B) Merged K - eTh - Total Magnetic Intensity (TMI) airborne radiometric and aeromagnetic image.

Figure 6: World Gravity Map (WGM2012) satellite gravity data of the Singo granite and surroundings. (A) Bouguer anomaly image. (2) $5 \mathrm{~km}$ upward continuation of the Bouguer anomaly data. 
Figure 7: Profiles and two-dimensional (2D) forward modeling of aeromagnetic data (A and B) and the WGM2012 satellite gravity data. See figures 3 and 6 for the location of the profiles.

Figure 8: Evolution of the Singo granite as a nested igneous ring complex. (A) Interpretation of the horizontal derivative image of the total magnetic field intensity data showing spatial extent of individual individual igneous ring complexes and possible migration direction with the igneous ring complex labeled (1) being the oldest and those labeled (4) being the youngest. (B-F) Five-step idealized model showing in cross-sectional view of possible progression of the magma plumbing system that resulted in the development of the Singo granite as a nested igneous ring complex. The baseline of the cross-section is shown in figure $8 \mathrm{~A}$ with the line labeled $\mathrm{X}-\mathrm{X}$ '. Please note that the sequence of numbering in figure $8 \mathrm{~A}$ and the sequence of appearance of magma plumbing system of individual igneous ring complexes do not imply that the migration of the magma plumbing system in different directions occurred concurrently. The geometry of individual igneous ring complex systems is adopted from Bonin (2007). 


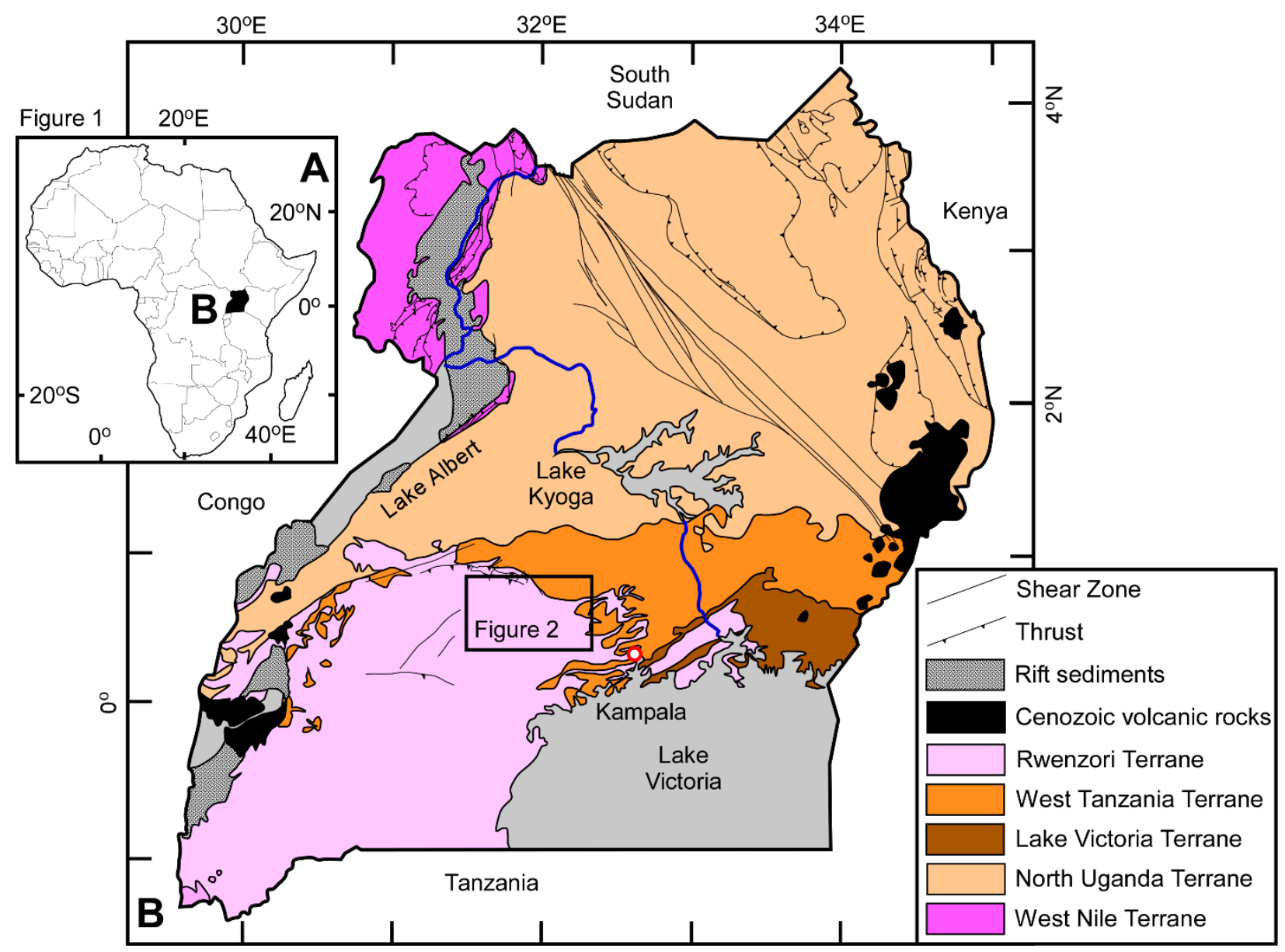




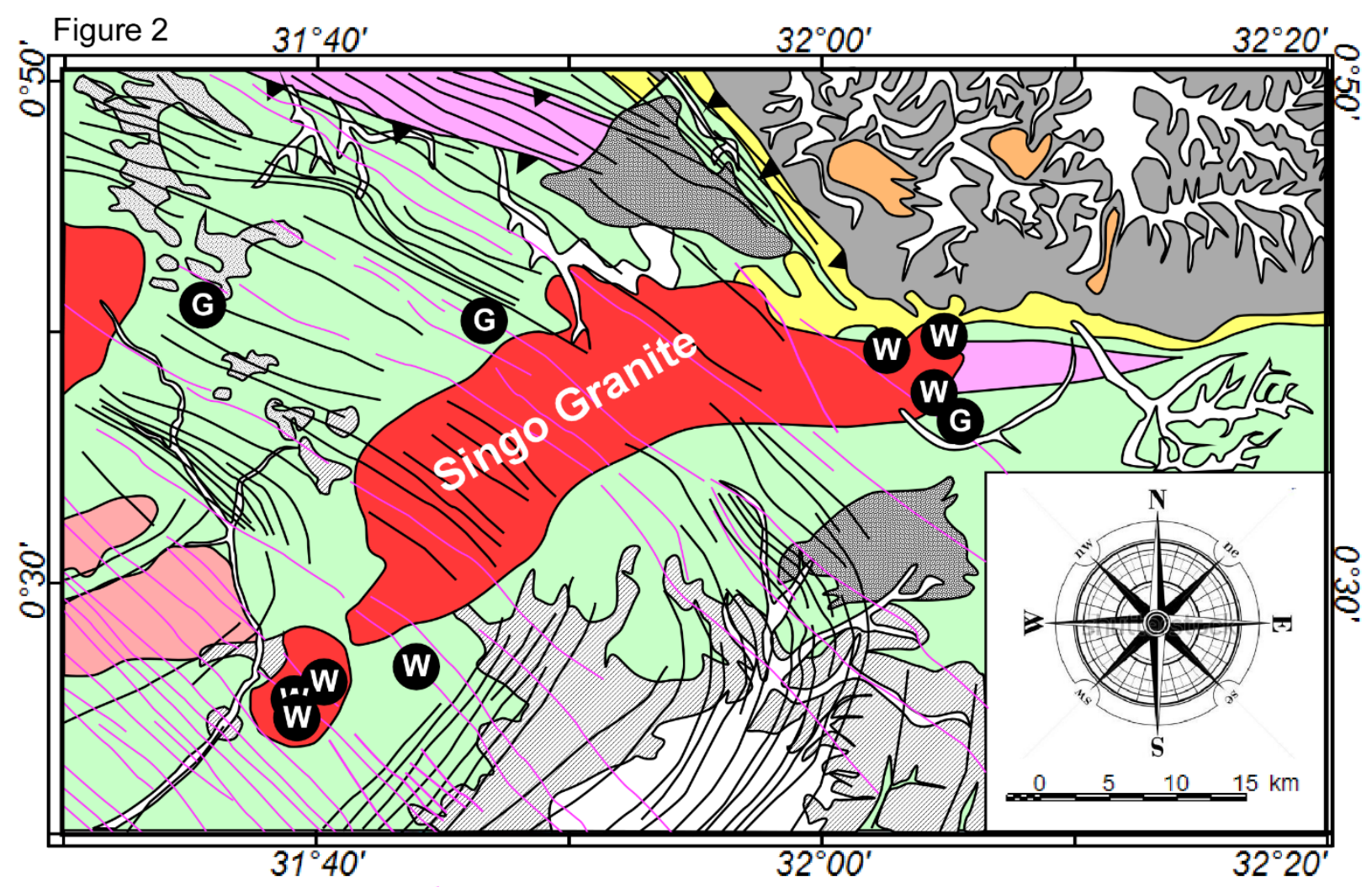

Post Singo granite emplacement dikes

Precambrian thrust

Trend of Precambrian regional fabric

Cover - Dominantly laterites

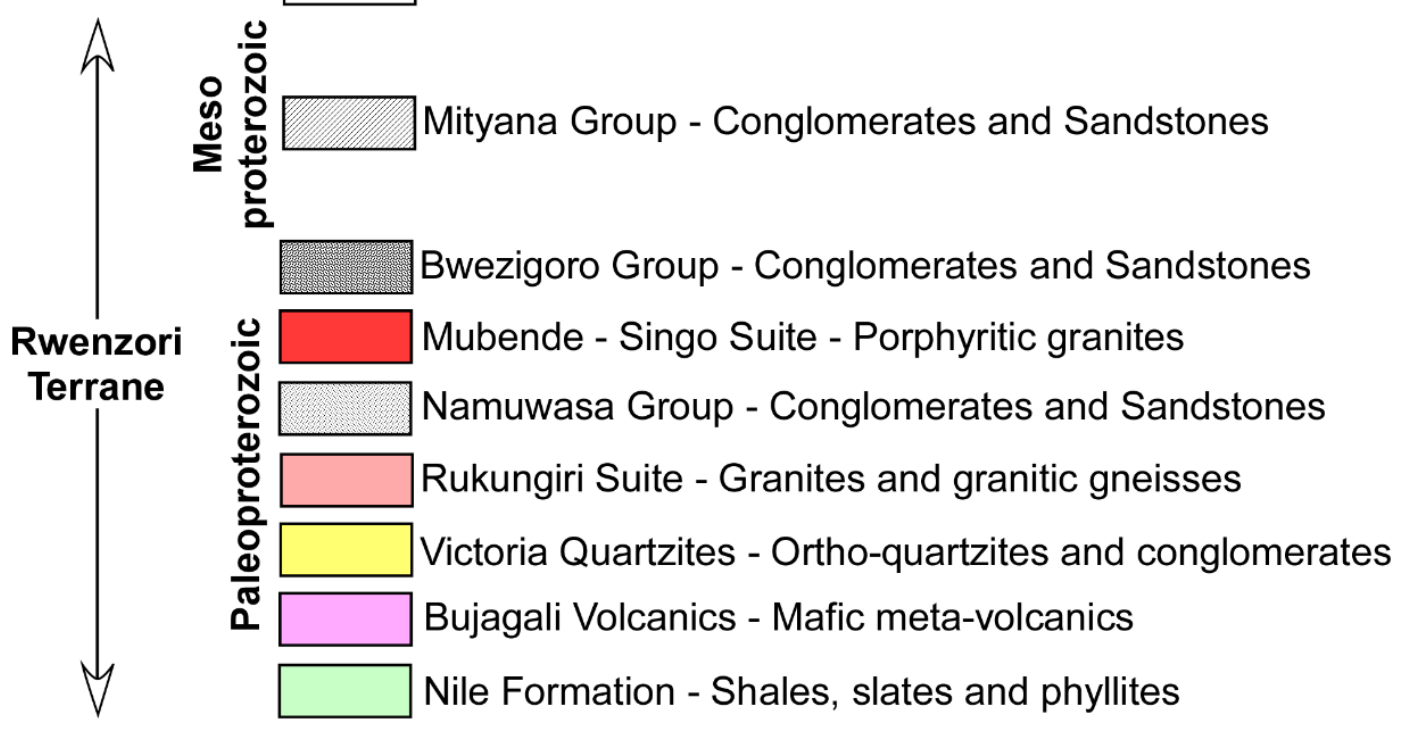

\begin{tabular}{cc|c|c|c|} 
West & Kiboga Suite - Porphyritic granites \\
Tanzania & Kampala Suite - Granitoids and orthogneisses \\
Terrane & Kam
\end{tabular} 


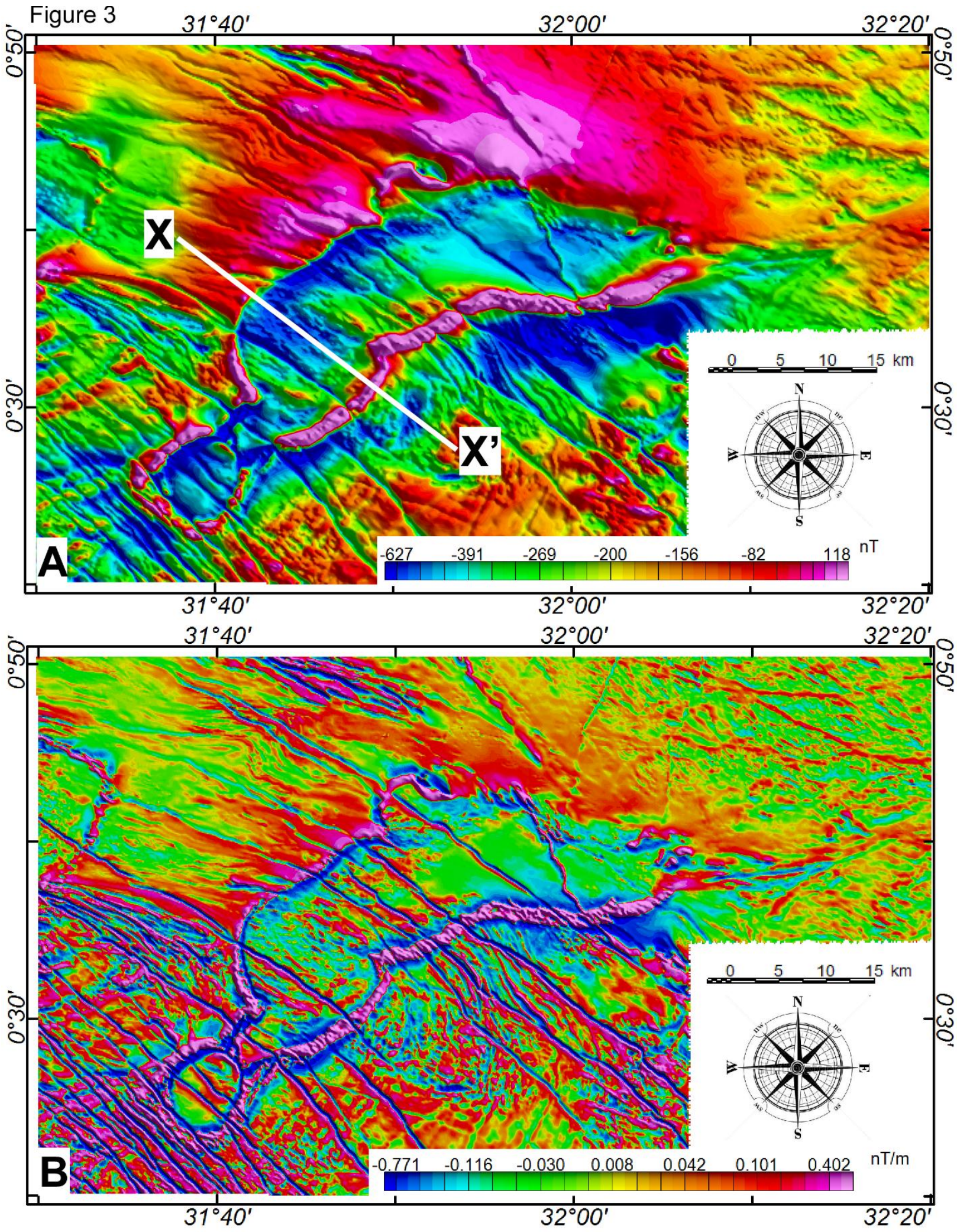


Figure 4
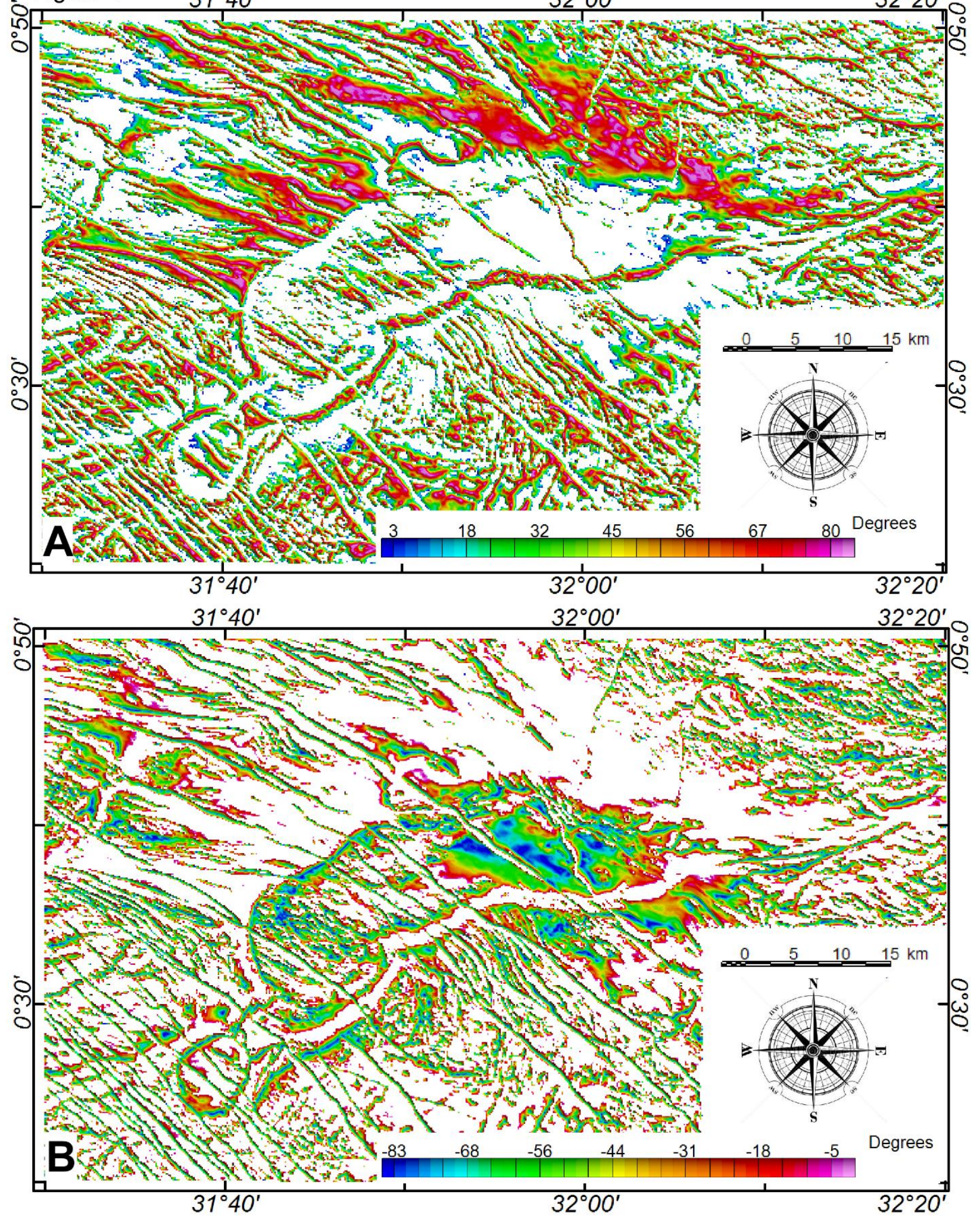


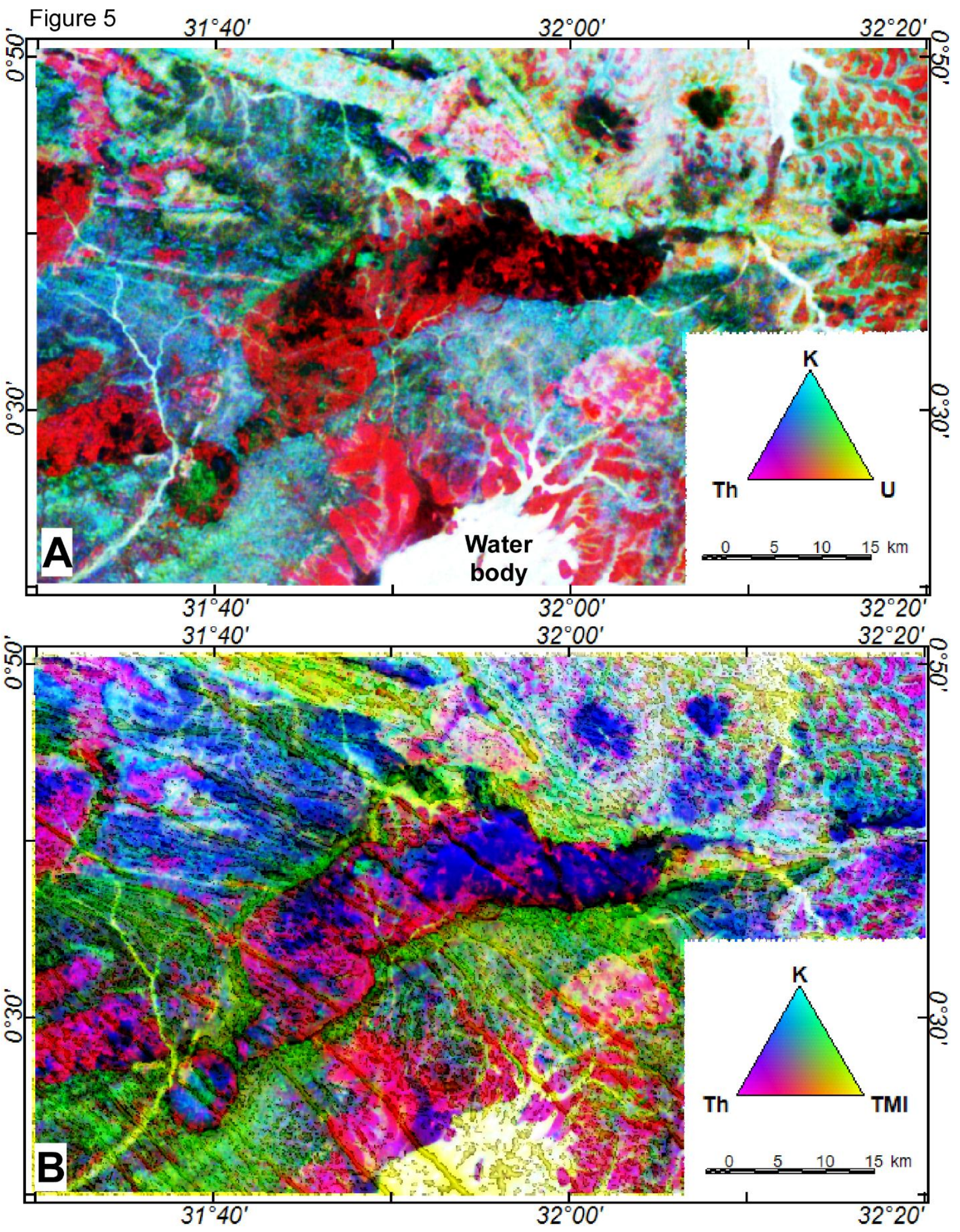




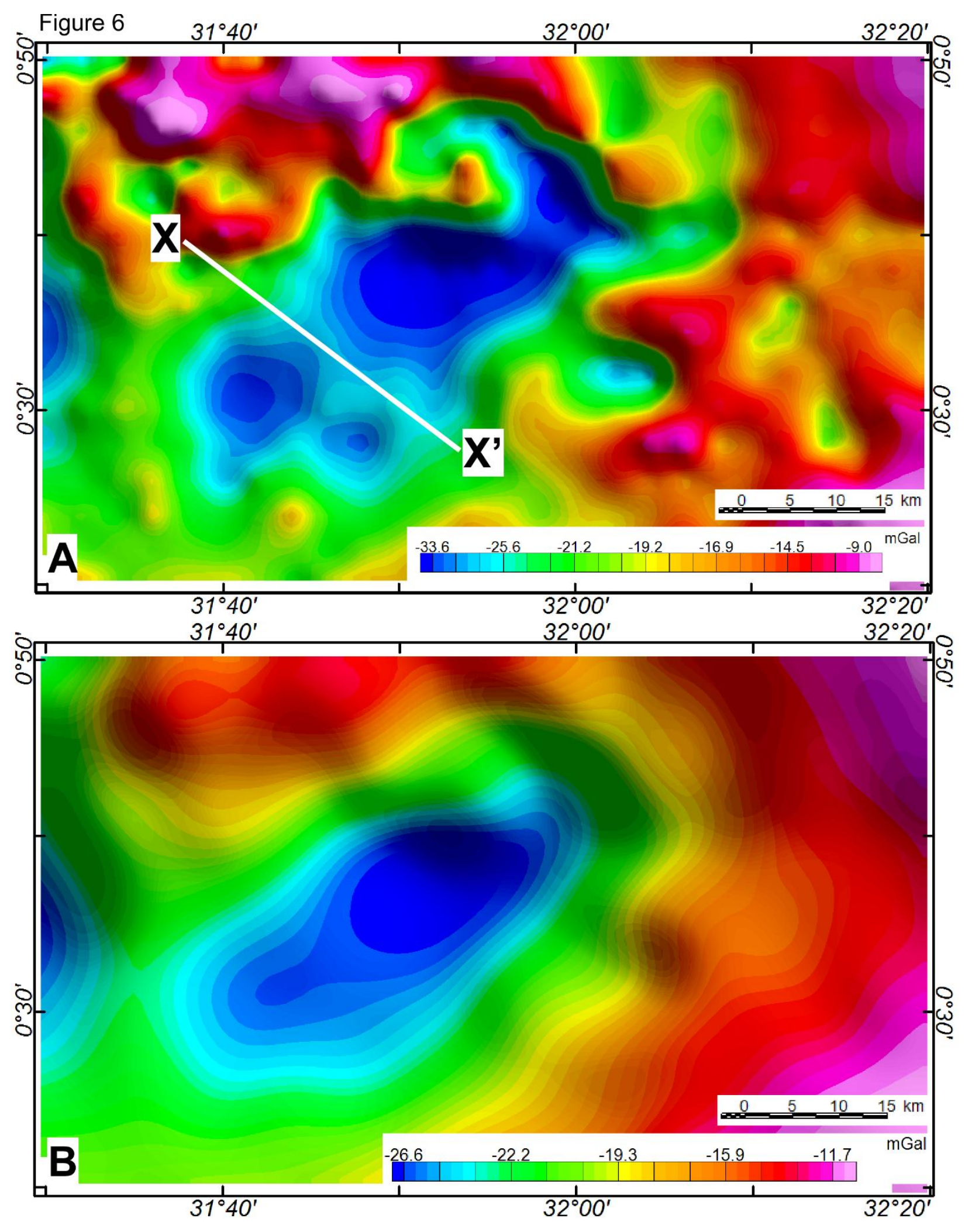


Figure 7
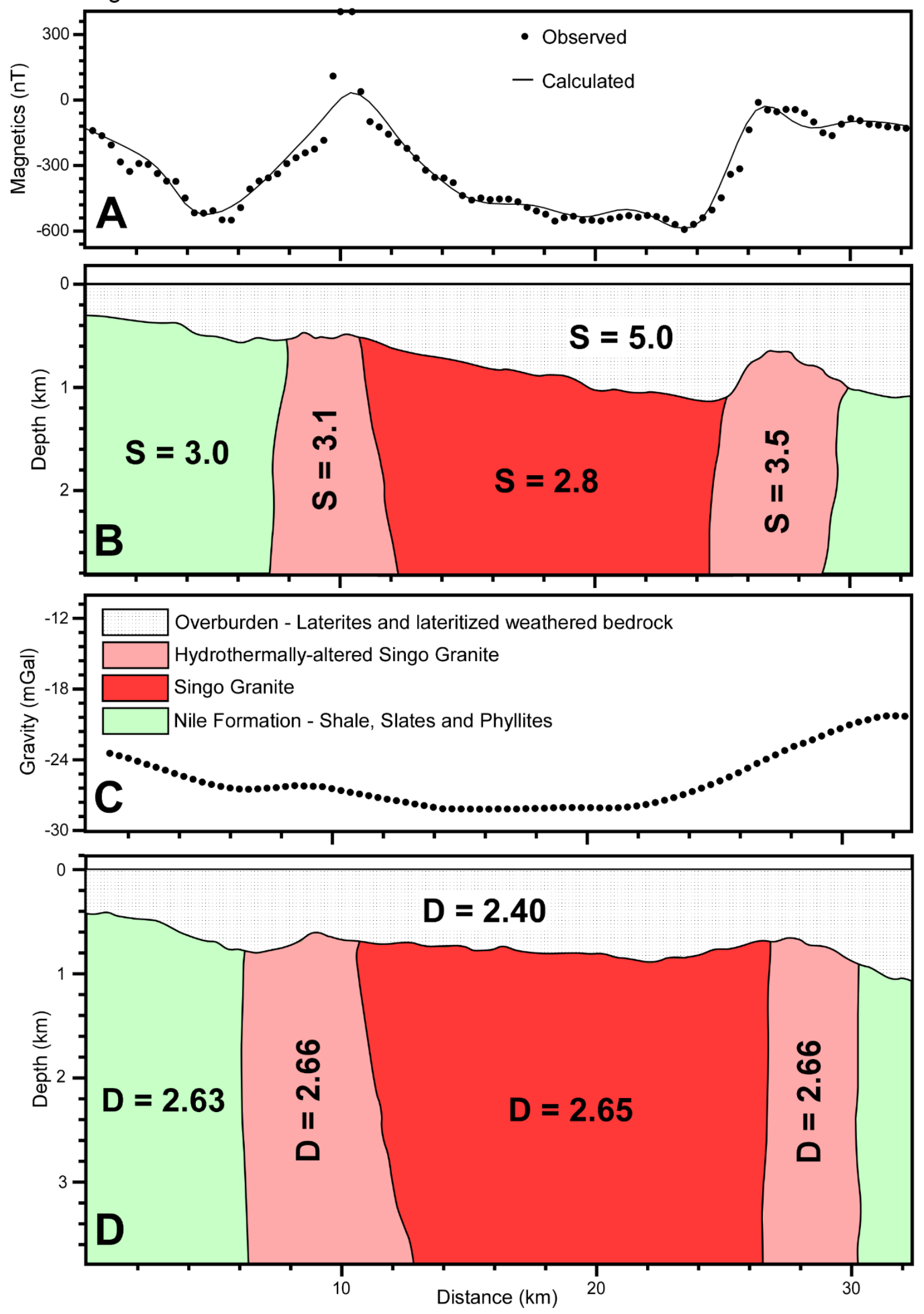

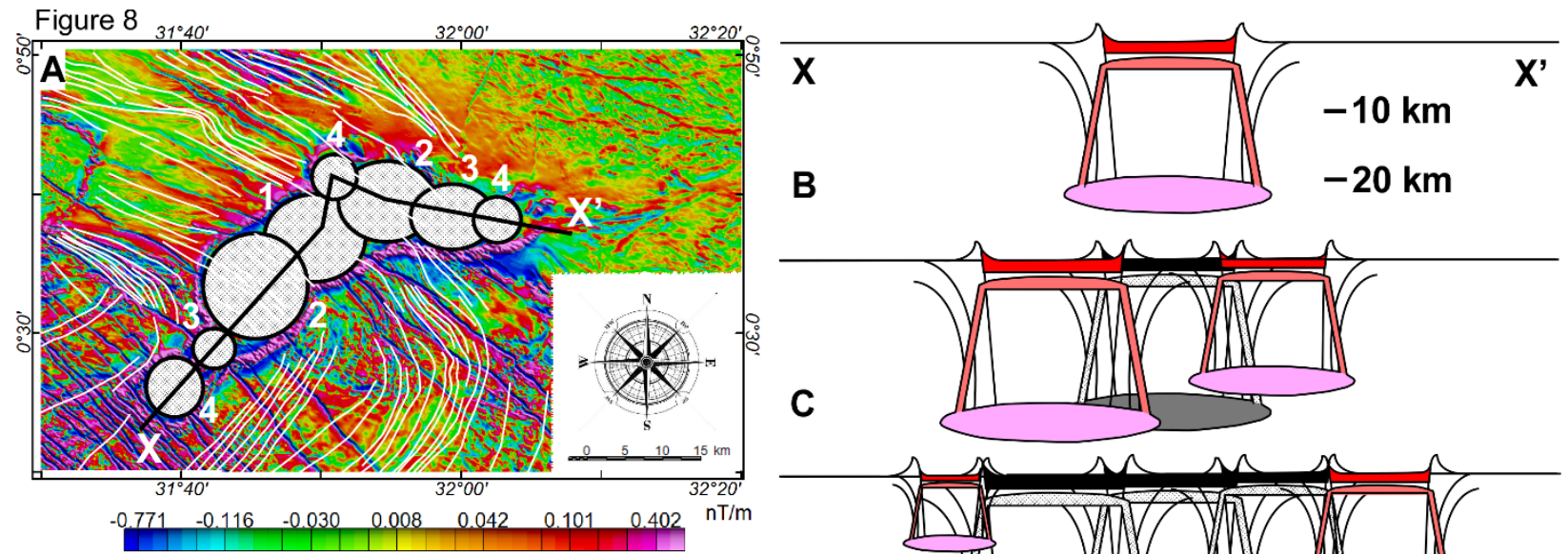

Present-day exposure level

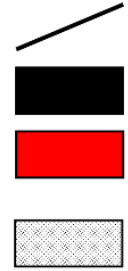

Ring fracture

Collapsed caldera

Active caldera

Crystallized subvolcanic intrusion and ring dike

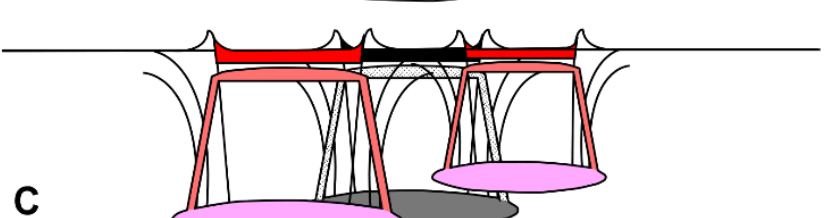

c

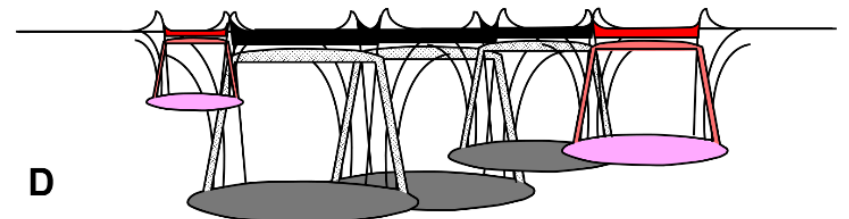
Emplacement of subvolcanic intrusion and ring dike

Crystallized magma chamber

Active magma chamber

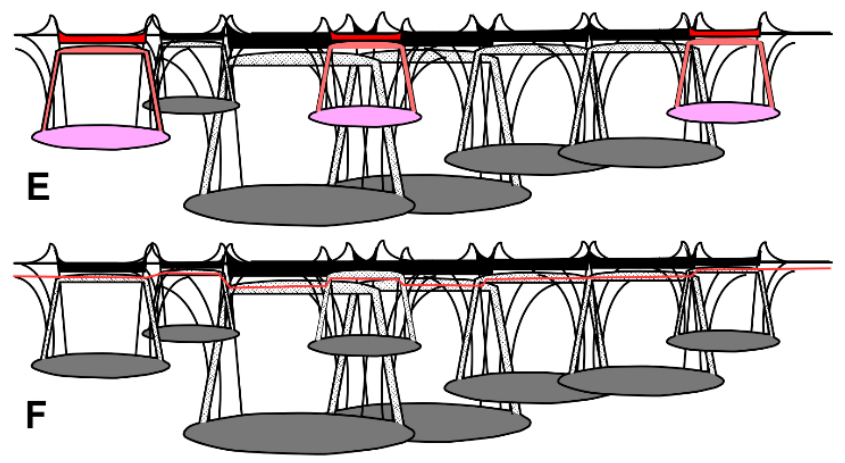



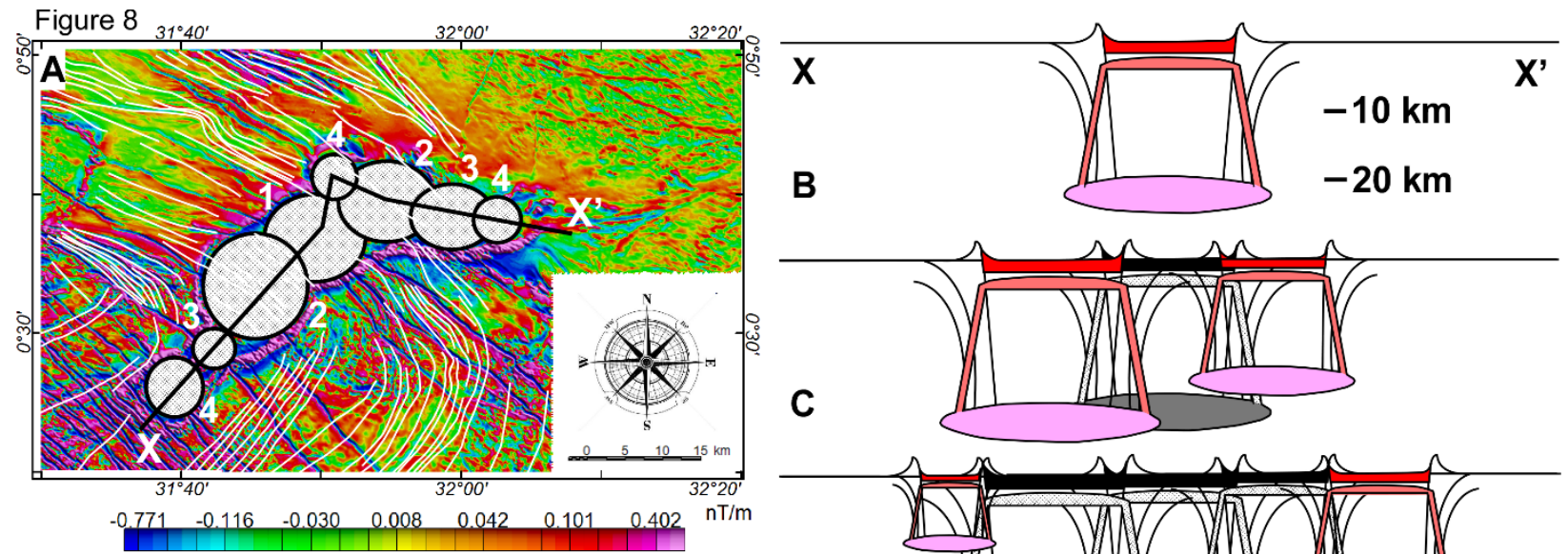

Present-day exposure level

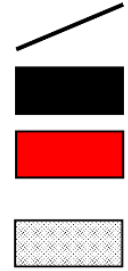

Ring fracture

Collapsed caldera

Active caldera

Crystallized subvolcanic intrusion and ring dike

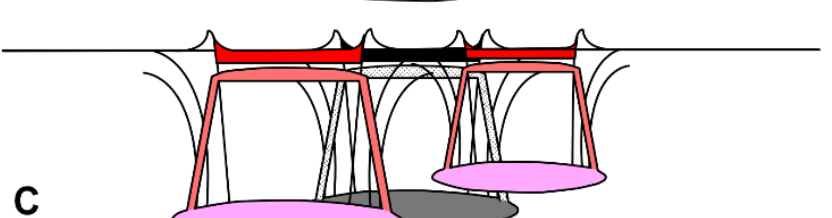

C

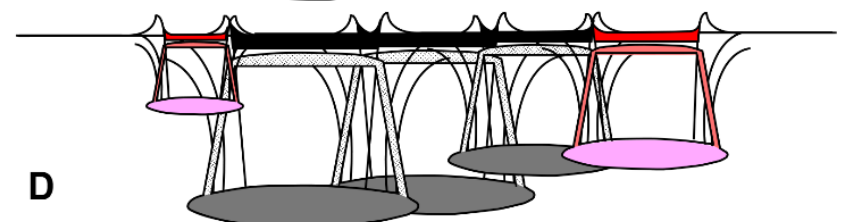
Emplacement of subvolcanic intrusion and ring dike

Crystallized magma chamber

Active magma chamber

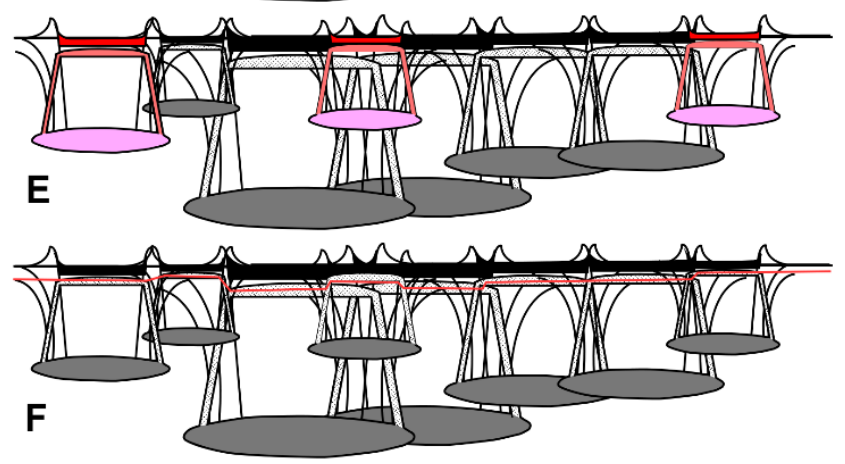

